\title{
The Good Judge of Château-Thierry and His American Counterpart
}

$\mathrm{T}$

HE name Château-Thierry awakens in American ears certain quite specific echoes. It is one of the few battlefields of the Great War that are likely to become colorful and stimulating names in future manuals of American history. But it is probable that Frenchmen-especially French lawyers-associate it primarily with an episode of an altogether different nature, namely, with the fact that for fifteen years the tribunal of the first instance at Château-Thierry had as its president M. Magnaud, called "le bon juge," "the good judge."1

M. Magnaud was the president of this tribunal between 1889 and 1904, after which time he entered the Parlement as a deputy and found an occasion to deliver a speech in defense of his judicial career. ${ }^{2}$ It is not too much to say that, in the period mentioned, M. Magnaud's decisions excited a wider interest than judicial decisions had ever before aroused in France, and became the subject of a more violent and bitter controversy than any others. This controversy was by no means confined to professional circles. Newspapers and magazines of all sorts-especially those of liberal or radical views-took the matter up. Anatole France extolled "le bon juge" in an article in Le Temps." In general, "advanced" opinion welcomed the innovator, while conservatives of all sorts, whether in law, in politics or in life, denounced him. Few echoes, to be sure, reached England or America, which maintained in this, as in so many other matters, their traditional legal isolation.

The book of M. Gény, cited before, ${ }^{4}$ permits us to form some accurate notion of what the elements in Magnaud's decisions were which so startled French opinion, and what the nature of this "phenomenon" was which provoked applause or alarm in most of the countries of continental Europe. ${ }^{5}$ Nearly all Magnaud's opin-

I It would be impossible in this connection to give any full description of the French judicial system. For the present, it may suffice to note that the Tribunal of First Instance is the court of largest original jurisdiction, that the Court of Appeal (Cours d'Appel) hears appeals from that court, and that the Court of Cassation in Paris, like the United States Supreme Court, is the court of highest appellate jurisdiction in the country.

2 Débats parlementaires, Sess, extraord. 1906, p. 3431, col. 3 . (Cited in Gény, Méthode d'interpretation en droit privé positif. (1919) ii, 302, n. 8.)

3 Now found in La Vie Litteraire.

4 Supra, n. 2.

5 Of the great importance of Gény's book, this is not the place to speak. It can only be hoped that in the very near future, both his Methode d'inter- 
ions were published in two separate volumes by H. Leyret: Les jugements du Président Magnaud (1900) and Les nouveaux jugements du Président Magnaud (1904). Unfortunately both of these books are already out of print. However, we find in Gény ${ }^{6}$ a fairly detailed account of them, and most of the information in the following pages is derived from this account.

The majority of the "good judge's" decisions were in no sense revolutionary. Generally, they were determinations of fact, which in civil matters wholly, and in criminal matters largely, are within the province of a French judge. Now, M. Magnaud leaned in favor of the weaker party - weaker, that is, because of poverty or social status-and if his sincerity be conceded, his opponents could scarcely quarrel with him, any more than with many another judge of his time, for exercising his discretion in accordance with his conscience. If one must decide as a matter of fact whether certain circumstances justified an assault or the discharge of an employee, it is difficult to see how a judge can really disregard his sympathies in estimating the justification. M. Magnaud sympathized with workmen and it was hard to convince him that a discharge was justified. He was indignant at the crime of seduction and it was easy to convince him that an assault on the seducer was justified. Juries in England and America, despite learned instruction, have human susceptibilities of a similar kind.

Secondly, wherever there were opposing legal theories, $M$. Magnaud selected the conclusion most in harmony with his liberal political and social views. To take a striking example, until the French Workmen's Compensation Law of 1898, there had been a division of opinion in French law as to the responsibility for industrial accidents. Under section 1382 of the Code Civil, the general principle was stated which made responsibility depend upon fault. The administrative court in the case of $\mathrm{Cames}^{7}$ declared the state responsible for an accident occurring in a public work, without proof of fault. The civil tribunals, with certain vacillations, clung to the theory of culpability as a basis of damages. ${ }^{8}$ M. Magnaud, one might well suppose, gave damages without proof of fault, making the obligation to compensate an implied term of the contract, under sec. 1135 and 1156 of the Code Civil-an interpreta-

pretation and his Science et Technique will be available in an English translation.

S Supra, n. 2 (op. cit., ii, 287-307).

7 Sirey, 1897, 3, 33, with the note of M. Hauriou.

8 An admirable history of the controversy is given in Charmont's brilliant and fascinating little book, Les Transformations du Droit Civil, pp. 232-254. 
tion which, as Saleilles showed, was dangerous to the theory he meant to advocate. In the same way, after the Workmen's Compensation Act, he extended the principle of responsibility without fault to cases in which passengers of railroads sued the carrier, although French courts had uniformly refused to do so until 1911.10 Again, he allowed good faith to be pleaded when damages were sought for statutory trespasses, such as hunting on another's land.

These and similar decisions, however bold, were not without support either in precedent, which French jurists term jurisprudence, or in authoritative discussion, la doctrine, but there was a group of his decisions which deliberately and defiantly set out on new courses.

Among the most striking of the decisions in this class were the following. $\mathrm{He}$ acquitted a self-confessed vagrant and mendicant, although the French law gives the judge no power to omit or suspend sentence when guilt is proved. He acquitted a woman who justified her theft of bread by a plea of hunger.11 In spite of Section 1385 of the Code which makes the owner of every animal absolutely liable for damage done by it, ${ }^{12}$ he refused to hold the owner of cattle found in the wrong pasture. Perhaps even more startling was his awarding a divorce on mutual consent, in explicit disregard of the fact that in 1884 this was abolished as a cause of divorce. ${ }^{13}$ Again, in France, when the communal regime is adopted by husband and wife, a legacy to either is, with certain exceptions, community property unless expressly made separate property. None the less, M. Magnaud refused a husband who had failed to perform his duties of support and administration any share in an annuity bequeathed to his wife. And no doubt commercial circles were

9 Saleilles, Les accidents du travail et la responsabilité civile. p. 20.

10 Gény, op. cit., ii, 295, n. 9. Sirey, 1913, 1, 177.

.11 Thomas Aquinas had like views on crimes justified by urgent necessity (Summa Theol. 22, q. 66, 7, 8). M. Magnaud, whose anti-clerical bias was only too apparent (Gény, p. 306, n. 1), would doubtless have rejected St. Thomas as an authority, but he could not have deprived him of his claim to priority.

12 The liability extends both to domestic animals and those ferae naturae. It is not quite absolute, but the only exculpation is vis maior or some similar wholly unavoidable contingency.

${ }_{13}$ Divorce by mutual consent was permitted by Sec. 233 of the Code Civil, a section forced by Napoleon himself on an unwilling commission. All the divorce provisions of the Code were abrogated at the Bourbon restoration in 18!6, and despite the virtual disestablishment of the church in 1848, these sections were not re-enacted till 1884, after a popular agitation of which Sardou's Divorçons is an amusing memorial. When they were restored, the section permitting divorce by mutual consent was designedly omitted. It is interesting to note that, in the twelve years in which Sec. 233 was in force, it was applied only once, in the divorce of Napoleon and Josephine. 
sufficiently agitated by his refusal to adjudicate a man a bankrupt, although the petition to do so in every way conformed to law, and by his suspension of bankruptcy proceedings in order to permit an amicable adjustment between the bankrupt and his creditors.

As illustrations of "impressionistic anarchy", "frankly arbitrary method", these decisions might have been taken merely as the vagaries of a weak but amiable sentimentality, scarcely justifying, in a system that repudiates stare decisis, the violent polemic waged against M. Magnaud in Germany and France. "His method", cried E. Jung," "is a denial of civilized law and an atavistic return to a primitive stage of juristic development. ... An incredible abuse ..." These are hard words for judgments which in the individual cases probably worked out substantial justice, and which created no bad law, because they were not followed. But $M$. Magnaud deemed it necessary to justify his decisions by general principles and the "attendu que" of his opinions, the introductory clauses, contain some dubious propositions. For example, in the vagrancy case, the judgment is introduced by the following: "In view of the fact that any person who demands and obtains a piece of bread to eat, impelled by the ineluctable needs of existence, is not guilty of the misdemeanor of mendicancy." Again in the case of theft, we read, "In view of the fact that hunger is capable of depriving any human being of a portion of his free will and diminishing in him, to a great extent, his notion of good and evil." These may be irrefragable positions in theology or psychology. They would need qualification as law. Or else M. Magnaud would allow himself to determine issues by such slightly irrelevant reflections as the following: "Uprightness and delicacy are virtues infinitely easier to practise when one lacks nothing than when one is absolutely destitute," or "the rights of the unfortunate should be safeguarded by a judge with even more solicitude than those of people favored by fortune." Admirable sentiments, doubtless, but even less capable of supporting judicial syllogisms than the honeste vivere of the Institutes.

M. Magnaud had a general policy. He scorned "legal law" (droit juridique, droit pur) and would be guided only by equitynot an altogether novel idea. In spite of the instances cited, he indignantly asserted he had never violated a law, i. e., a statute, however much he may have trampled upon la jurisprudence. "The judges of the tribunal of Château-Thierry," he stated in the speech

14 Positives Recht, pp. 23-24, cited in Gény, n. 303, n. 4. 
already cited, ${ }^{15}$ "derived their decisions from their consciences alone and rendered judgments that seemed equitable to them, because they always kept in mind that the legislature could have intended only an equitable result, and that if the text of a statute seemed apparently to lead to inequity, it is incontestable that this inequity was not intended by the legislature." One can travel far with such a theory. Perhaps not farther than isolated judges have travelled or sought to travel in America. ${ }^{16}$ But it is a somewhat uncharted sea. We should be glad to have assurance that our sense of equity and natural right was less fallible than such things often are, before we could confidently substitute them for the express wording of a law. M. Magnaud no doubt was so assured, but few of his colleagues shared his feeling.

For he had practically no following on the bench. M. Gény, the protagonist in France of the "free-law school," repudiates all connection with his view. ${ }^{17} \mathrm{He}$ even notes maliciously that $M$. Magnaud's speeches in the Chamber of Deputies are frequently verbatim quotations of his judicial opinions, a circumstance that is significant enough of the "good judge's" real capacities and the proper field for their exercise. If Magnaud had been somewhat less the avowed exponent of a social and political program, he might have made his insistence on a fully humane and social comprehension of the facts in every given case, and his determination to interpret accepted law in the most equitable way possible, a fruitful and beneficent tendency in French jurisprudence.

The importance of the "phénomène Magnaud" is not altogether that of a phenomenon. A recent judicial experiment in North Dakota has given us an episode strikingly similar in its tendencies and results to that of the work of Magnaud in France. The judges of the Non-Partisan League ${ }^{18}$ might with profit study the career of the good judge of Chatteau-Thierry, both for examples of what to do and what to avoid. Perhaps no better example of the fact that similar forces will manifest themselves similarly can be found than the marked resemblance in tone as well as substance of these

15 Supra, n. 2.

16. There is not much difference between Magnaud's theory of statutory interpretation and that stated in a recent California case, Newhall Land Co. v. Hogue-Kellogg Co. (1921) 37 Cal. App. Dec. 105: "But we think it clear that if such a case is to be brought within section 3313 [of the Civil Code], that section must be given such a construction as to lead to a reasonable result."

17 Gény, op. cit.. vol. ii, p. 304.

18 Andrew Bruce, The Non-Partisan League, pp. 170 seq. Reviewed by Professor Kidd in 10 California Law Review, 269. 
opinions. M. Mágnaud shocked French opinion not only by what he decided, but also by the bitterness of his invectives against certain social institutions. But more even than that, his vindictive hostility to specific courts such as the Court at Amiens or to the Ministry of Justice, astounded and offended a profession trained to vigorous but courteous disputation.

France is, at the present time, facing a real tendency of courts to direct, somewhat as American courts have done, the development of social institutions. It is curious that the section of public opinion which is most energetically combatting this tendency is the very section that applauded $M$. Magnaud when he undertook, in the interest of liberal politics, to assert a judicial supervision of those public functions which are ordinarily removed by the French system from the control of courts.

Now "good judges" are not unknown to the Anglo-American system, if by "good" judges we mean those who have attempted, as freely as they could, to determine causes in accordance with their personal sympathies or personal conscience. Since hard cases make bad law, such "good" will almost by definition be "bad" judges in the common-law sense, when they disregard the plain meaning of a statute, or contradict what a series of binding precedents has established within their own jurisdiction. It is evident that this disregard and contradiction must, in a system based on stare decisis, be somewhat indirect. Judges_"good" or "bad"have rarely avowed that they are overruling established law. They "distinguish," "interpret," "explain," "reconcile," often with a finesse that would have delighted the angelic and subtle Doctors of the Middle Ages or the rabbinical pundits of Sora and Pumbeditha. And yet stare decisis is not an inflexible rule, and has almost nowhere been so treated. Courts have often-and openlyrefused to follow it when the previous decisions were plainly erroneous. ${ }^{19}$ Not only does the United States Supreme Court decline to be bound by those of its previous decisions which it deems wrong, but conservative jurisdictions like Massachusetts and judges like Rugg J., can state "The doctrine of stare decisis does not prevent re-examination and correction of principles previously declared."20 Or else we may read that courts "should examine their previous decisions without reluctance and correct them without

$19 \mathrm{Cf}$. the formidable array of citations in the article on Courts, 15 Corpus Juris 956, \& 357.

${ }_{20}$ Commonwealth v. Walsh (1907) 196 Mass. 369, 82 N. E. 19, 124 Am. St. Rep. 559. 
hesitation."21 Of this freedom in dealing with precedents, the bête noir of "good judges," there could be no more striking example than a decision of Chief Justice Parsons of New Hampshire, who in 1907 overruled Pinnel's case, ${ }^{22}$ although the rule in that case was three hundred years old, was supported by the overwhelming majority of common-law jurisdictions and by a long series of New Hampshire decisions. ${ }^{23}$

Where the binding force of precedents is questioned by a court, it is generally because the precedent as originally established was itself contrary to precedent, that is, was not a correct statement of the law deemed to have pre-existed. That is often an illusion, and even a half-conscious fiction, but not infrequently it is true enough. We have seen, however, that M. Magnaud scorned precedent, la jurisprudence, not because it was an inaccurate declaration of the law, but because it was inequitable, because it did not do justice in the specific case before him. In this, he was justified by the principles of the system within which he worked, a system that never accepted stare decisis. Our judges who attempt to apply his methods would constitute a "phenomenon" even more emphatically than he did.

And such a judicial phenomenon has appeared recently in the person of Mr. Justice James E. Robinson of North Dakota. Elected in 1916 by an unprecedented majority, he took office on January 2, 1917, as a Non-Partisan League partisan with the avowed intention of sweeping away the dry-rot of technicalities and precedents and deciding every case on the merits as they appeared to his conscience. There is a striking similarity between Mr. Robinson and M. Magnaud. Both are earnest; both immensely confident in their rectitude; both active politicians; both radical in their views and sympathies; both dislike lawyers; and both have scant awe for their colleagues.

But there the similarity ends. Of the two, the Frenchman is much the more consistent and much more consciously determined to carry out the principle that immediate justice must be done to the litigants, whatever statute or precedent say. Mr. Justice Robinson is not so free from the wickedness of seeking support in adjudicated cases as he likes to believe. It is true in a recent

${ }^{21}$ Kimball v. Grantsville (1899) 19 Utah 397, 57 Pac. 1,8 seq., 45 L. R. A. 628.

225 Coke 117, 77 English Reports Reprint 237. 1197.

23 Frye v. Hubbell (1907) 74 N. H. 358, 68 At1. 578, 17 L. R. A. (N. S.) 
case $^{24}$ he referred to the citing of certain old decisions as supporting a "tweedledum and tweedledee objection." But in Krapp v. Krapp, ${ }^{25}$ and in Bowman v. Retelieuk, ${ }^{26}$ in Miller v. Little, ${ }^{27}$ as in many other of his prolific prevailing, concurring, partially concurring, dissenting and partially dissenting opinions, he cites cases to bolster up his views and with apparent satisfaction. Indeed, in the last instance, it is the authority of these cases that seems to him to conclude the question. It is true that, in general, he cites fewer cases than his colleagues. But that does not quite mean that he deliberately disregards them. Often his views are fully in accord with precedent-and arbitrary technical precedent. A professional tax-title lawyer before being a judge, he would decide the case of McDonald v. Hansen ${ }^{28}$ on a defect in the tax-title deed. He finds a wrong remedy selected in Cooper v. Gordon, ${ }^{29}$ and particularly in Sexton v. Sutherland ${ }^{30}$ he sustains that crowning wickedness, a demurrer based upon an incorrect form of action. And within the same year, we read the following language from the lips of one who would do equity though the heavens fell: "In a statutory action like this, it is sheer folly for counsel to talk about rules of equity. It is a case of strict law, and not of equity."31 M. Magnaud, to do him justice, never talked of strictum ius, except to abuse it. It is evident that Judge Robinson is not above doing so. One might almost suppose the decision to be given by Blackburn or Kenyon, instead of the judge who several times repeated the phrase "Every man may demand of the courts right and justice, without sale, denial or delay." 32

As in the case of Maguaud, much the larger number of Judge Robinson's decisions, even when he supposes them to be violent departures from established rules, can be paralleled elsewhere. His language is more violent and picturesque than that of other judges, but that is all. If it is "radical" to limit the rule of stare decisis, then many courts have been as "radical" as he has, although they have not deemed it necessary in overruling a case to say: "That decision does violence to our conscience and our sense of fairness

24 Merchants Bank v. Streeper (1921) 186 N. W. 100 (N. D.).

25 (1921) 186 N. W. 754 (N. D.)

26 (1918) 40 N. D. 134, 168 N. W. 576.

27 (1917) 37 N. D. 612,164 N. W. 19.

28 (1917) 37 N. D. 612, 164 N. W. 19.

29 (1917) 37 N. D. 247,164 N. W. 21.

30 (1917) 37 N. D. 440,164 N. W. 42.

31 Great Northern Railway v. Grand Forks County (1917) 38 N. D. 1, 164 N. W. 320.

32 Bismark Water Supply Co. v. Burleigh County (1917) 36 N. D. 191, 161 N. W. 1009. 
and honesty.... It was for that evil practise the Master said: 'Woe unto you, ye lawyers." "s3

Judge Robinson's theory of the function of an appellate tribunal may be said to be the following. The case comes to him and to his colleagues upon stated points and exceptions. These he considers, in most cases, as pure excrescences on the record. The testimony is before him and this alone he asserts that he examines. If the testimony convinces him in favor of the plaintiff or of the defendant, he decides accordingly. "As the verdict is clearly right, there is no occasion for a discussion of the testimony or the assignment of errors." ${ }^{34}$ "The findings are sustained by convincing evidence. Hence it is needless to discuss any other question." ${ }^{35}$ The difficulty is that Judge Robinson is convinced where others might not be, and just as Magnaud is inclined to credit a tale of unmerited suffering, so our Dakotan "bon juge" is.much moved by the recitals of "plain, hardworking, simple people." His decision in Wisterland v. First National Bank of Carrington ${ }^{38}$ is entirely based on the sufferings of an unfortunate Norsk (sic!) who, he violently asserts, had been hoodwinked by the bank. But there was testimony on the other side sufficient to convince the majority of the court. If we had only Judge Robinson's dissent before us, we should never imagine that there was any dispute as to the testimony. That, in fact, is just the danger inherent in such a process as Judge Robinson's. If an appellate tribunal retries an issue of fact without sight of the witnesses or renewed examination of them, the judge will inevitably find himself acting as counsel for the side that engages his sympathies, even to the extent of raising points on appeal that they had never raised. This is an ancient and evil practise and Judge Robinson has doubtless found in his theological reading the maxim of Rabbi Judah b. Tabbai who in 100 B. C. said: "In the judge's seat, act not the counsel's part."

It must not be supposed that Judge Robinson's announcements, even when startling in form and unusual in substance, are all mischievous in tendency. Certainly more than one judge would heartily accede to his impatience with pleadings that make legal procedure "a game of chance . . turning on the skill or adroitness of counsel"; $;$ and more than one would wish that his suggestion

33 Wilhelm v. Bang (1921) 184 N. W. 268 (N. D.).

34 Johnson Co. v. Hildreth (1921) 185 N. W. 811 (N. D.).

35 Shark v. Great Northern Railway (1917) 37 N. D. 440,164 N. W. 42. 36 (1917) 38 N. D. 24,164 N. W. 326.

37 Canon Charles Taylor, Sayings of the Jewish Fathers (Pirke Abot) i. 8. 38 Weber v. Interstate Business Men's Association (1921) 184 N. W. 97 , 104 (N. D.). 
in Olson v. Horton Motor Co. ${ }^{39}$ could be followed, in which he desires to make an attorney party plaintiff when it appears that he has a fifty per cent interest in the outcome of the suit. Again, we could only wish that some of his later lucubrations had the terseness and directness of one of his earlier opinions, such as that of Crowson v. Minneapolis St. Ry. Co., ${ }^{40}$ which, quoted in full, runs as follows: "I approve this decision. It would be a great detriment to the public if railway trains were to move like teams. They must go. It is the duty of every person to use great care and caution in crossing a railroad track."

However, the real difficulty with Judge Robinson is the one that vitiated the legal results of Magnaud's work. He mistook his forum. It may be true that judges have in many cases used their great office to support and extend certain set political doctrines, but few have done so in so flagrant or inconsistent a manner as Judge Robinson. His opposition to the inheritance tax law reads less like a legal argument than a political pamphlet. ${ }^{41}$ But his gross violation of all canons in this regard are best illustrated by his conduct before election, ${ }^{42}$ and by such decisions as Langer $v$. Courier News Co., ${ }^{43}$ Langer v. Fargo. ${ }^{44}$ The most outrageous instance is Wilson v. City of Fargo, ${ }^{45}$ in which he sets aside explicit constitutional provisions with the contemptuous statement that the people had progressed considerably since they "swallowed the constitution whole as the whale swallowed Jonah." The direct partisan purpose of this decision, overladen with phrases of great moral earnestness, is indicated by the fact that on another occasion he denounced an act which violated the very constitutional safeguard he here sets aside. ${ }^{46}$

Courts have in past times wrapped themselves too much in their dignity. But there seems no sufficient reason why the language even of "good" judges, should not be the language of a gentleman. M. Magnaud apparently manages to phrase his objections to set institutions in the diction of cultivated and adult men. It really is not necessary to say that the defendant was a "goosie" or a "sucker" 47 in order to do equity. There is, further, a certain

39 (1921) 185 N. W. 365,368 (N. D.).

to (1917) 36 N. D. 100,161 N. W. 725.

41 Moody v. Hazen (1917) 36 N. D. 471,162 N. W. 709.

42 Bruce, The Non-Partisan League, pp. 170 seq.

\$3 (1921) 186 N. W. 102 (N. D.).

44 (1921) 186 N. W. 104 (N. D.).

45 (1921) 186 N. W. 263,266 (N. D.).

16 Bruce, The Non-Partisan League pp. 181-183.

47 Wolf v. Wolf (1918) 41 N. D. 109, 169 N. W. 577 ; Ryan v. Bremseth (1921) 186 N. W. 823 (N. D.). 
jocularity apparent in his reference to marital or sex relations, which is not so much undignified as it is unpleasant. ${ }^{48}$ Then, we have such expressions as those of Blumardt v. McDonald :49 "In this case it is extremely hard to write a dissent without using swear words. . . . This is awful." For this we can find no better rebuke than his own words in City of Minot v. Olson :50 "In the conduct of a legal proceeding the rules of common courtesy must prevail."

Enough has been said to show that amidst all similarities between the French and the American "bons juges," the differences are still more striking. M. Magnaud is a consistent and conscious radical. His decisions, which impressed his colleagues as "impressionistic anarchy," follow a set policy. Judge Robinson would scarcely be recognized as a radical in France or even as a liberal. In fact he can be quoted for points of view that might be called reactionary and blindly conservative. It is the veering inconsistency in his practise, more than the vague looseness of his professions that make his "jurisprudence" an evil example. Indeed, it is not too much to say that his theory amounts to no more than this: any proposed action or enactment of the League must be sustained and that the sustaining rhetoric may be adjusted to the needs of the moment; while for any case that does not involve League action, the Supreme Court must retry the issue of fact on the record presented, sometimes exalting the function of a jury in set words, and sometimes disregarding that body with scarcely concealed contempt. ${ }^{51}$

M. Magnaud has long been off the bench and had little influence on it, except perhaps to indicate to his opponents that his methods are as available for reactionary politicians as for radical ones. Judge Robinson is still on the bench. It may be suggested that if he studies the career of his French colleague he will learn that sincerity and earnestness and a certainty of rectitude may not save his record from being remembered chiefly as an example to be avoided..$^{52}$

University of California,

Max Radin.

Berkeley, California.

48 Ford v. Ford (1919) 173 N. W. 454 (N. D.) ; Worlitz v. Miller (1921)

184 N. W. 809 (N. D.).

${ }_{49}^{\circ}(1917)-36$ N. D. 518,162 N. W. 412.

so (1919) 173 N. W. 461 (N. D.).

51 Reid y. Ehr (1917) 36 N. D. 552, 162 N. W. 907; Beardsley v. Ewing (1918) 40 N. D. 373, 168 N. W. 791, 795.

- 82 A brief discussion of Judge Robinson's activities will be found in 33 Harvard Law Review, 972-976. Cf. especially Bruce, Judicial Buncombe in North Dakota, 88 Central Law Journal, 136, and Judge Robinson's reply, 88 Central Law Journal, 155. 